\title{
Material Analysis of Nickel Superalloy for Military Technology
}

Petr Jonšta ${ }^{1}$, Irena Vlčková ${ }^{2}$, Zdeněk Jonšta ${ }^{3}$

${ }^{1}$ VÍTKOVICE HEAVY MACHINERY a.s., Ruská 2887/101, Vítkovice, 70300 Ostrava, Czech Republic, E-mail: petr.jonsta@vitkovice.cz

${ }^{2}$ RMTSC, MATERIAL \& METALLURGICAL RESEARCH Ltd., Ostrava, remote site VÚHŽ a.s., 73951 Dobrá, Czech Republic, E-mail: vlckova@vuhz.cz

${ }^{3}$ Technical University of Ostrava, Faculty of Metallurgy and Materials Engineering, 17. listopadu 15/2172, 70833 Ostrava-Poruba, Czech Republic, E-mail: zdenek.jonsta@vsb.cz

In the aerospace industry, the nickel-based superalloys are often used due to their ability to withstand extreme conditions. They find their use particularly as turbine blades in jet engines. An important example of this type of superalloy is INCONEL. This construction material must meet a wide range of complex requirements with regard to its properties and technological and operational characteristics that are required by the heavy duty in extreme conditions.

The INCONEL Superalloys represent multicomponent and multiphase materials with their complex alloying base and structure with distinct dendritic segregations. Their long life and reliability in operation are directly related to the microstructure, or to its stability in a long-term operational application, respectively.

The presented work deals with the evaluation of microstructural parameters at two variants of cast superalloy INCONEL 713LC, applying the light microscopy and electron microscopy, including the fractographic analysis.

Keywords: Nickel superalloy, as cast condition, structural phase analysis, fractography

\section{Acknowledgments}

This work was created during the implementation of the project no. LO1203 "Regional Materials Technology Centresustainability program" funded by the Ministry of Education, Youth and Sports of the Czech Republic.

\section{References}

[1] High Temp. Alloys for Gas Turbines and Other Appl., Proc. Int. Conf. Liege (1976, 1986, 1990, 1994, 1998).

[2] SCHUBERT, F. (1978). Hochtemperaturwerkstoffe fur den Receiver des Solar Systems, Studie fur die DFVLR.

[3] SIENIAWSKI, J. (1995). Kryteria i sposoby oceny materiałów na elementy silników turbinowych, Politechnika Rzeszowska.

[4] SIMS, C. T., STOLAFF, N. S., HAGEL, W. C. (1998) Superalloys II. Wiley \& Sons, New York (1987).

[5] KOIZUMI, Y., KOBAYASHI, T. et al. (1998) In: High Temp. Mat. for Power Eng., P.II, Liege' 98.

[6] HERNAS, A., JONŠTA, Z., et. al. (2009). Žárupevné oceli a slitiny, ES VŠB-TU Ostrava, 392 p.

[7] BELAN, J., HURTALOVÁ, L., VAŠKO, A., TILLOVÁ, E. (2014). Metallography Evaluation of IN 718 after Applied Heat Treatment. Manufacturing Technology. Vol. 14, No. 3. ISSN 1213-2489.

[8] DONACHIE, M., J., DONACHIE, S., J. (2002) Superalloys: a technical guide, USA, 439 p.

[9] STRANG, A. (1998). High Temp. Mat. for Power Eng. and Other Appl., Liege'98.

[10]CRANE, F. A., CHARLES, J. A. (1986). Selection and Use of Engineering Materials, Butterworths, LondonWellington.

[11]BELAN, J., KUCHARIKOVÁ, L., TILLOVÁ, E., UHRIČÍK, M. (2015). The Overview of Intermetallic Phases Presented in Nickel Base Superalloys after Precipitation Hardening. Manufacturing Technology. Vol. 15, No. 4. ISSN 1213-2489.

[12]JONŠTA, Z., JONŠTA, P., VODÁREK, V., MAZANEC, K. (2007) Physical-Metallurgical Characteristics of Nickel Super Alloys of INCONEL Type. Acta Met.Slovaca, 13, (4).

[13]VILAMOVÁ, Š., JANOVSKÁ, K., KOZEL, R.,VOZŇÁKOVÁ, I., ŠVECOVÁ, E. (2012). New Trends in the Management within the Metallurgy Firms. International Conference on Metallurgy and Materials Metal 2012. Ostrava: Tanger, pp. 1897-1903. 